\title{
Peningkatan Keterampilan Bagi Ibu Rumah Tangga dalam Rangka Penghematan Melalui Pembuatan Sabun Cair Sederhana
}

\author{
Andrian Haro \\ Universitas Negeri Jakarta, Indonesia, andrian.haro@unj.ac.id \\ Agung AWS Waspodo \\ Universitas Negeri Jakarta, Indonesia, awaspodo@gmail.com \\ Agung Wahyu Handaru \\ Universitas Negeri Jakarta, Indonesia, ahandaru@ unj.ac.id
}

\begin{abstract}
The consumption pattern of housewives in several things has already changed. Recently, there are so many housewives are switching to use liquid soap for cleaning their kitchen utensils. This is due to the ease of use of product and the affordable price. Regarding to this, the team held an activity which aimed to improve the skills and knowledge of housewives, especially in IKADANA groups at Srengseng, West Jakarta, through the production of simple liquid soap in order to make savings in household consumption expenditure. This activity is performed by using the survey and demonstration method. The result showed that almost all participants have understood the process of making simple liquid soap and so far they were interested to try further in their own home. One of the benefits of making this liquid soap is to save household expenditure, especially the consumption of liquid soap. In addition to this, the housewives became open-minded and motivated to make their skills as a side business or home industry to improve their household economy.
\end{abstract}

Key words: entrepreneurship, home industry, liquid soap

PENDAHULUAN

\section{Analisis Situasi}

Dewasa ini perilaku konsumsi dan kebiasaan para ibu rumah tangga telah mengalami perubahan dalam beberapa hal. Perubahan perilaku yang dapat dilihat dari keseharian seorang ibu rumah tangga adalah aktivitas mereka 
dalam mencuci peralatan rumah tangga dan dapur. Beberapa waktu yang silam, para ibu rumah tangga menggunakan abu gosok, sabun pasta/krim atau gabungan dari keduanya untuk mencuci peralatan dapur. Memang tidak bisa dipungkiri bahwa intensitas pemakaian sabun dalam kehidupan sehari-hari terbilang rutin dikonsumsi. Hal ini dikarenakan fungsi utama dari sabun yang bersifat membersihkan atau mengangkat kotoran yang menempel pada sebuah permukaan. Oleh karena itu, dapat dikatakan bahwa pengeluaran rutin bagi ibu rumah tangga tiap bulannya sebagian dialokasikan untuk pembelian sabun cuci.

Seiring perkembangan teknologi dan perubahan zaman, banyak sekali bentuk dan jenis sabun yang ditawarkan kepada konsumen di pasar mulai dari sabun cuci (krim dan bubuk), sabun mandi (padat dan cair), sabun tangan (cair) serta sabun pembersih peralatan rumah tangga dan dapur (krim dan cair). Umumnya dikalangan ibu rumah tangga, pengeluaran konsumsi sabun yang terbilang sering adalah sabun cuci piring. Produk Pencuci piring pada prinsipnya terbagi ke dalam tiga jenis yang berdasarkan atas penampilan fisiknya. Pertama adalah sabun bubuk atau serbuk, kedua sabun pasta atau krim, dan ketiga berbentuk cairan.

Sabun cuci bubuk atau scouring powder sepertinya kurang dikenal oleh masyarakat, meskipun pernah dijual di swalayan. Produk kedua, sabun pasta/krim atau yang lebih dikenal dengan sabun colek terbilang produk pencuci piring yang sering dibeli konsumen dipasaran. Dan produk ketiga pencuci piring berbentuk cairan kental, dimana produk ini yang paling banyak dibeli dan dikonsumsi oleh konsumen dikalangan ibu rumah tangga. Dari tiga jenis produk pencuci piring yang ditawarkan kepada konsumen, dapat dikatakan bahwa kecenderungan pemakaian sabun cuci cair dari waktu ke waktu mengalami peningkatan yang cukup pesat.

Peningkatan konsumsi sabun cuci cair ini dapat dipahami bahwa kebiasaan/pola pencucian piring para ibu rumah tangga (termasuk alat rumah tangga lainnya) sudah mulai bergeser, dimana pergeseran itu terlihat konsumen sudah pelan-pelan meninggalkan cara tradisional yang 
menggunakan abu gosok dan sabun colek menuju cara baru yang lebih praktis. Kehadiran sabun cuci cair ini memberikan kepraktisan dalam penggunaan untuk membersihkan peralatan makan seperti piring, gelas, sendok/garpu dan peralatan dapur pada umumnya. Selain itu, kecepatan sabun cair dapat larut baik didalam air dan aroma produk yang khas menjadikan cairan pencuci piring ini mempunyai nilai lebih dibanding produk pencuci piring lainnya seperti sabun cuci krim yang memberikan efek kurang lembut ditangan dan meninggalkan aroma sabun krim pada peralatan dapur. Faktor keuntungan lainnya bila menggunakan sabun cuci cair ini bila ditinjau dari sisi kesehatan tergolong lebih higienis.

Oleh karena itu, kebutuhan akan produk sabun cair semakin lama semakin meningkat. Maka banyak sekali produk-produk sabun cair yang bisa ditemukan pada berbagai jenis pasar. Pada prinsipnya dalam pembuatan sabun cair ini tidak memerlukan bahan dan peralatan yang rumit. Untuk proses produksinya tidak serumit bila dibandingkan dengan pembuatan sabun pembersih lainnya (pasta atau powder). Selama ini sebagian masyarakat menganggap pembuatan sabun suci cair sulit, padahal bahan-bahan bakunya mudah didapatkan pada toko-toko bahan kimia dengan harganya yang terjangkau.

Melalui kegiatan pengabdian pada masyarakat ini diharapkan dapat memberikan keterampilan dan pengetahuan kepada masyarakat khususnya ibu rumah tangga pada kelompok pengajian IKADANA di daerah Srengseng, Jakarta Barat, tentang pembuatan sabun cuci cair sederhana. Dengan adanya pelatihan ini, para ibu rumah tangga bisa mempraktikkan sendiri di rumah dan bisa melakukan penghematan pengeluaran konsumsi rumah tangga, khususnya konsumsi sabun cuci cair.

\section{Perumusan Masalah}

Berdasarkan analisis situasi di atas, maka perumusan masalah adalah bagaimana cara meningkatkan keterampilan dan pengetahuan ibu rumah tangga pada kelompok pengajian IKADANA di daerah Srengseng, Jakarta Barat, melalui pembuatan sabun cair sederhana dalam rangka penghematan pengeluaran konsumsi? 


\section{Tujuan Kegiatan}

Tujuan pengabdian masyarakat ini adalah untuk meningkatkan keterampilan dan pengetahuan ibu rumah tangga pada kelompok pengajian IKADANA di daerah Srengseng, Jakarta Barat, melalui pembuatan sabun cair sederhana dalam rangka penghematan pengeluaran konsumsi.

\section{Manfaat Kegiatan}

Dengan diadakan kegiatan pengabdian pada masyarakat ini, diharapkan memberikan manfaat kepada peserta antara lain:

1. Meningkatkan keterampilan dan pengetahuan bagi ibu rumah tangga pada kelompok pengajian IKADANA di daerah Srengseng, Jakarta Barat, melalui pembuatan sabun cair sederhana dalam rangka penghematan pengeluaran konsumsi rumah tangga, khususnya sabun cuci cair.

2. Menumbuhkan dan meningkatkan motivasi ibu rumah tangga pada kelompok pengajian IKADANA di daerah Srengseng, Jakarta Barat, untuk menjadikan keterampilan yang mereka peroleh sebagai usaha sampingan atau bisnis rumah tangga (home industry) untuk meningkatkan perkonomian rumah tangga mereka.

\section{KAJIAN TEORITIK}

\section{Pengeluaran Konsumsi}

Konsumsi

merupakan pembelanjaan atas barang dan jasa oleh rumah tangga yang bertujuan untuk memenuhi kebutuhan atas orang yang melakukan pembelanjaan tersebut. Konsumsi masyarakat dapat dikategorikan ke dalam konsumsi makanan dan bukan makanan. Barangbarang yang diproduksi untuk digunakan oleh masyarakat untuk memenuhi kebutuhannya dinamakan barang konsumsi (Shciffman dan Kanuk, 2010).

Pengeluaran konsumsi seseorang adalah bagian dari pendapatan yang dibelanjakan. Menurut Dumairy (2004), pengeluaran konsumsi rumah tangga adalah semua pembelian barang dan jasa oleh rumah tangga yang tujuannya untuk dikonsumsi selama periode tertentu dikurangi neto penjualan barang bekas. Oleh karena itu, motif atau pola konsumsi suatu kelompok masyarakat terutama sangat ditentukan pada pendapatan yang diterima. Dengan 
demikian secara umum dapat dikatakan bahwa tingkat pendapatan yang berbeda-beda menyebabkan

keanekaragaman konsumsi suatu masyarakat atau individu.

\section{Sabun Cair}

Sabun merupakan campuran garam alkali (natrium atau kalium) dari asam lemak monocarboxylic yang dapat diturunkan dari minyak atau lemak yang direaksikan dengan alkali (seperti natrium/kalium hidroksida) pada suhu $80-100{ }^{\circ} \mathrm{C}$ melalui proses saponifikasi (Jongko, 2009). Sabun adalah surfaktan yang digunakan dengan air untuk mencuci dan membersihkan. Sabun biasanya berbentuk padatan tercetak yang disebut sabun batang, tetapi sekarang penggunaan sabun cair telah meluas dipasaran. Jika diterapkan pada suatu permukaan, air bersabun secara efektif mengikat partikel dalam suspensi sehingga mudah dibawa oleh air bersih.

$$
\text { Sabun berfungsi untuk }
$$

mengemulsi kotoran berupa minyak atau zat pengotor lainnya. Saat ini teknologi pembuatan sabun telah berkembang pesat. Jenis dan bentuk sabun yang dihasilkan cukup bervariasi dipasaran, mulai dari sabun mandi, sabun cuci, baik untuk pakaian maupun untuk peralatan rumah tangga. Kandungan zat yang terdapat pada sabun juga bervariasi sesuai dengan sifat dan jenis sabun. Zat-zat tersebut dapat menambah kualitas produk sabun, baik dari nilai guna maupun dari daya tarik konsumen.

\section{Kewirausahaan}

Bila ditinjau dari segi bahasa, kewirausahaan berasal dari kata dasar wirausaha, dimana kata tersebut terdiri atas dua kata, yaitu wira dan usaha. Dengan demikian definisi kewirausahaan adalah kemampuan kreatif dan inovatif yang dijadikan dasar, kiat, dan sumber daya untuk mencari peluang menuju sukses. Wirausaha adalah seseorang yang memiliki kemampuan dalam menggunakan dan mengkombinasikan sumber daya seperti keuangan, material, tenaga kerja, keterampilan untuk menghasilkan produk, proses produksi, bisnis dan orgasisasi usaha baru (Longenecker, Moore dan Patty, 2001).

Berdasarkan pendapat Meredith et al. (2002) secara umum, wirausaha memiliki dua peran, yaitu penemu (innovator) dan sebagai perencana 
(planner). Sebagai penemu wirausaha menemukan dan menciptakan produk baru, teknologi dan cara baru, ide-ide baru, dan organisasi baru. Sedangkan sebagai perencana, wirausaha berperan merancang usaha baru, merencanakan strategi perusahaan baru, merencanakan ide-ide dan peluang dalam perusahaan, dan menciptakan organisasi perusahaan baru.

Kewirausahaan adalah suatu kemampuan untuk mengelola sesuatu yang ada di dalam diri seseorang untuk dimanfaatkan dan ditingkatkan agar lebih optimal (baik) sehingga bisa meningkatkan taraf hidup di masa mendatang (Meredith et al., 2002). Kewirausahaan meliputi ilmu pengetahuan, kepribadian atau sikap, filosofi, dan keterampilan.

Menurut Aprijon mengatakan salah satu faktor pendorong pertumbuhan kewirausahaan disuatu negara terletak pada peranan universitas melalui penyelenggaraan pendidikan kewirausahaan. Oleh karena itu, perlu dibina kepribadian individu yang sangat mempengaruhi keberhasilan usaha. Dengan memiliki jiwa pemimpin, siap mental untuk menghadapi segala resiko dan tantangan dalam hidupnya.

\section{MATERI DAN METODE}

\section{Kerangka Pemecahan Masalah}

Dalam pengabdian pada masyarakat ini, peserta diberikan sekilas informasi tentang penghematan pengeluaran konsumsi dan anggaran rumah tangga terkait penggunaan produk sabun cuci cair. Selain itu, peserta akan diberikan demonstrasi mengenai tata cara pembuatan sabun cair sederhana yang ekonomis dan terjangkau oleh peserta, sehingga dapat membantu proses penghematan pengeluaran konsumsi rumah tangga, khususnya konsumsi sabun cuci cair.

\section{Realisasi Pemecahan Masalah}

Sebelum kegiatan pengabdian pada masyarakat ini dilakukan, terlebih dahulu dilakukan penyebaran kuesioner kepada para peserta dengan tujuan untuk mengetahui profil ibu rumah tangga yang menjadi target sasaran kegiatan pelatihan. Setelah mengetahui profil ibu rumah tangga tersebut, kegiatan dilanjutkan dengan menyiapkan materi pelatihan yang mudah dimengerti oleh peserta 
pelatihan menggunakan metode klasikal berupa diskusi, paparan, dan simulasi, sedangkan untuk tata cara pembuatan sabun cair sederhana menggunakan metode demonstrasi dan praktik.

\section{Khalayak Sasaran}

Kegiatan pengabdian pada masyarakat ini ditujukan bagi ibu rumah tangga pada kelompok pengajian IKADANA di daerah Srengseng, Jakarta Barat, sebagai sasaran kegiatan. Latar belakang pendidikan dan ekonomi yang digolongkan ke dalam kelompok masyarakat ekonomi menengah dianggap relevan dalam kegiatan ini. Para ibu rumah tangga tersebut selain mengurusi kebutuhan rumah tangganya juga membutuhkan keterampilan dan pengetahuan dalam melakukan penghematan pengeluaran konsumsi rumah tangga, dalam hal ini konsumsi sabun cuci cair. Selain itu, para ibu rumah tangga membutuhkan inspirasi dan motivasi terkait peluang bisnis rumah tangga yang dapat mereka ciptakan melalui keterampilan pembuatan sabun cuci cair ini.

\section{Metode Penerapan}

Metode penerapan yang dilakukan pada kegiatan ini berupa diskusi, paparan, dan simulasi, sedangkan untuk tata cara pembuatan sabun cair sederhana menggunakan metode demonstrasi atau praktik. Metode demonstrasi adalah cara penyajian pelatihan dengan memeragakan suatu proses kejadian. Peragaan yang dilakukan adalah proses pembuatan sabun cair sederhana. Metode ini digunakan dengan asumsi bahwa peserta akan lebih mudah untuk memahami dan mudah untuk diingat karena peserta dapat melihat langsung bagaimana proses pembuatannya, dimana mayoritas peserta adalah ibu rumah tangga sehingga dalam praktik pembuatan sabun cair ini dapat dikatakan menyerupai proses memasak kue yang memerlukan takaran dalam pembuatannya.

Dalam proses praktik atau demonstrasi pembuatan sabun cair ini diperlukan bahan baku, yaitu Texapon (N-70), Sodium Sulfat $\left(\mathrm{Na}_{2} \mathrm{SO}_{4}\right)$, garam $(\mathrm{NaCl})$, parfum, warna, dan air destilasi. Sedangkan peralatan yang digunakan berupa timbangan, wadah gelas, batang pengaduk, spatula, dan pipet tetes. Langkah yang harus dilakukan dalam proses pembuatan ini terlebih dahulu 
masing-masing bahan baku ditimbang sesuai dengan berat yang telah ditentukan. Selanjutnya tahapan yang dilakukan, antara lain:

1. Mencampurkan Texapon (N-70) dan Sodium Sulfat ke dalam wadah gelas lalu diaduk hingga merata,

2. Menambahkan sebagian air destilasi ke dalam campuran tersebut dan dilanjutkan pengadukan kembali hingga tercampur baik,

3. Menambahkan garam $(\mathrm{NaCl})$ yang sudah dilarutkan terlebih dahulu dengan air destilasi ke dalam campuran sebelumnya, kemudian dilanjutkan pengadukan kembali,

4. Menambahkan parfum, warna, dan sisa air destilasi ke dalam campuran tersebut dan tetap dilakukan pengadukan hingga tercampur dengan baik,

5. Mendiamkan hasil pencampuran tersebut paling lama kira-kira semalam.

6. Sabun cair sederhana siap untuk digunakan.

\section{HASIL DAN PEMBAHASAN}

Kegiatan pengabdian pada masyarakat ini dilakukan pada tanggal
25 Oktober 2016 yang bertempat di kediaman salah satu anggota pengajian IKADANA di Srengseng, Jakarta Barat. Acara ini dihadiri oleh para peserta yang merupakan anggota pengajian IKADANA yang terdiri dari para ibu rumah tangga sebanyak 20 orang. Di dalam kegiatan ini terlebih dahulu dilakukan survei kepada para peserta menggunakan kuesioner untuk mengetahui profil dari peserta yang akan mengikuti kegiatan pelatihan. Hasil dari kuesioner tersebut dapat dilihat pada tabel 1 .

Tabel 1. Statistik Demografik Peserta $(\mathrm{N}=20)$

\begin{tabular}{|c|c|c|c|}
\hline Demografik & & $\mathbf{f}_{\mathbf{i}}$ & $(\%)$ \\
\hline \multirow[t]{4}{*}{ Usia } & 1)18-23 Tahun & - & - \\
\hline & 2)24-30 Tahun & - & - \\
\hline & 3)31-40 Tahun & 8 & 40,0 \\
\hline & 4)> 40 Tahun & 12 & 60,0 \\
\hline \multirow[t]{4}{*}{ Pendidikan } & 1)SMP & 3 & 15,0 \\
\hline & 2)SMA & 12 & 60,0 \\
\hline & 3)Diploma (D3) & 1 & 5,0 \\
\hline & 4)Sarjana (S1) & 4 & 20,0 \\
\hline \multirow[t]{4}{*}{ Status Pernikahan } & 1)Belum & - & - \\
\hline & Menikah & & \\
\hline & 2)Menikah & 15 & 75,0 \\
\hline & 3)Janda & 5 & 25,0 \\
\hline \multirow{3}{*}{$\begin{array}{l}\text { Pekerjaan } \\
\text { Sampingan }\end{array}$} & 1) $\mathrm{Ya}$ & - & - \\
\hline & & & \\
\hline & 2)Tidak & 20 & 100 \\
\hline \multirow[t]{3}{*}{ Penghasilan/bulan } & 1) $<$ Rp 1 juta & - & - \\
\hline & 2)Rp 1-2 juta & 14 & 70,0 \\
\hline & 3)Rp 2-4 juta & 6 & 30,0 \\
\hline Pengeluaran/bulan & 1)Rp $500.000-$ & - & - \\
\hline
\end{tabular}




\begin{tabular}{|c|c|c|c|}
\hline & \multicolumn{3}{|l|}{ Rp 1 juta } \\
\hline & 2)Rp 1-2 juta & 7 & 35,0 \\
\hline & 3)Rp 2-3 juta & 13 & 65,0 \\
\hline Pembelian Sabun & 1) $\mathrm{Ya}$ & 20 & 100 \\
\hline Cuci Cair & 2)Tidak & - & - \\
\hline Merek Sabun & 1)Sunlight & 13 & 65,0 \\
\hline Cuci Cair & 2)Mama Lemon & 7 & 35,0 \\
\hline
\end{tabular}

Kondisi demografik yang dapat digambarkan dari 20 responden adalah paling banyak usia ibu rumah tangga di atas 40 tahun yaitu 12 orang (60\%), sebagian besar dari mereka tingkat pendidikan terakhirnya adalah SMA sebanyak 12 orang (60\%) dengan status pernikahan mereka adalah menikah sebanyak 15 orang (75\%). Mayoritas dari 20 peserta (100\%) adalah ibu rumah tangga yang tidak memiliki pekerjaan sampingan dengan penghasilan keluarga atau rumah tangga per bulan rata-rata sebesar Rp 2-4 juta yaitu 14 orang (70\%). Sedangkan pengeluaran konsumsi rumah tangga per bulan rata-rata sebesar Rp 2-3 juta yaitu 13 orang (65\%), dimana dari 20 peserta $(100 \%)$ semuanya melakukan pengeluaran konsumsi rumah tangga atau pembelian terhadap sabun cuci cair dengan merek produk yang paling banyak digunakan oleh ibu rumah tangga adalah Sunlight sebanyak 13 orang $(65 \%)$.

Setelah hasil kuesioner didapatkan, maka langkah selanjutnya adalah melakukan pelatihan kepada ibu rumah tangga pada kelompok pengajian IKADANA di daerah Srengseng, Jakarta Barat, berupa pembuatan sabun cuci cair sederhana. Pelatihan ini menggunakan teknik demonstrasi atau praktik langsung dihadapan para peserta ibu rumah tangga. Namun, sebelum pelatihan ini dilakukan terlebih dahulu diberikan penjelasan secara singkat terkait penggunaan bahan baku kimia, fungsi dari bahan baku, dan harga dari bahan baku kimia yang akan digunakan dalam pembuatan sabun cuci cair sederhana serta tempat pembelian bahan bakunya. Untuk informasi tentang formulasi dan harga pembuatan sabun cuci cair selengkapnya dapat dilihat pada tabel 2 .

Untuk bahan baku kimia yang digunakan dalam pembuatan sabun cuci cair ini diperoleh dari toko kimia yang ada di Jakarta Pusat yaitu CV. Harum Kimia. Satu demi satu bahan baku kimia dijelaskan kepada para peserta pelatihan. Respon peserta ibu rumah 
tangga tersebut sangat antusias dan mereka menyimak dengan baik informasi yang diberikan serta mereka aktif bertanya terkait proses pembuatan sabun cuci cair ini, seperti terlihat pada gambar 1.

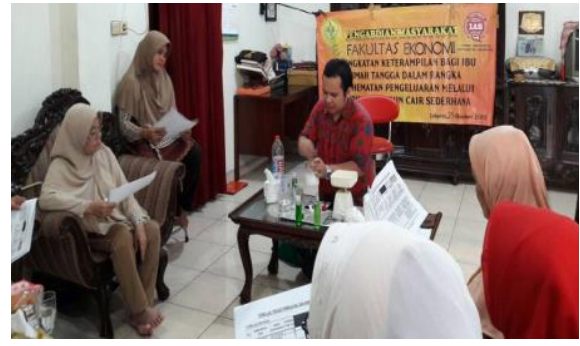

Gambar 1. Pelatihan Pembuatan Sabun Cuci

Cair

Tabel 2. Formulasi dan Harga Pembuatan Sabun Cuci Cair Sederhana

\begin{tabular}{|c|c|c|c|c|c|c|c|c|c|c|}
\hline No & $\begin{array}{c}\text { Bahan } \\
\text { Baku }\end{array}$ & Fungsi & Harga & $(\%)$ & (gr) & (Rp) & (gr) & (Rp) & (gr) & (Rp) \\
\hline 1 & $\begin{array}{l}\text { Texapon } \\
(\mathrm{N}-70)\end{array}$ & Surfaktan & $\begin{array}{l}\mathrm{Rp} \\
35.000 / \\
\mathrm{kg}\end{array}$ & 10 & 10 & Rp350 & 50 & $\mathrm{Rp} 1,750$ & 100 & Rp3,500 \\
\hline 2 & $\begin{array}{l}\text { Sodium } \\
\text { Sulfat } \\
\left(\mathrm{Na}_{2} \mathrm{SO}_{4}\right)\end{array}$ & $\begin{array}{l}\text { Booster } \\
\text { Surfaktan; } \\
\text { Pengental }\end{array}$ & $\begin{array}{l}\mathrm{Rp} \\
6.000 / \mathrm{kg}\end{array}$ & 5 & 5 & Rp30 & 25 & Rp150 & 50 & Rp300 \\
\hline 3 & $\begin{array}{l}\text { Garam } \\
(\mathrm{NaCl})\end{array}$ & Pengental & $\begin{array}{l}\mathrm{Rp} \\
6.000 / \mathrm{kg}\end{array}$ & 1 & 1 & Rp6 & 5 & Rp30 & 10 & Rp60 \\
\hline 4 & Parfum & Pewangi & $\begin{array}{l}\mathrm{Rp} \\
2.000 / \mathrm{ml}\end{array}$ & 0.5 & 0.5 & Rp100 & 2.5 & Rp500 & 5 & Rp1,000 \\
\hline 5 & Warna & Pewarna & $\begin{array}{l}\mathrm{Rp} \\
1.000 / \mathrm{gr}\end{array}$ & 0.03 & 0.03 & Rp30 & 0.15 & Rp150 & 0.3 & Rp300 \\
\hline 6 & Air & Pelarut & - & $\begin{array}{l}83.47 \\
100 \\
\%\end{array}$ & $\begin{array}{l}83.47 \\
\mathbf{1 0 0} \\
\text { gram }\end{array}$ & Rp516 & $\begin{array}{l}417.35 \\
\mathbf{5 0 0} \\
\text { gram }\end{array}$ & Rp2,580 & $\begin{array}{l}834.7 \\
\mathbf{1 . 0 0 0} \\
\text { gram }\end{array}$ & Rp5,160 \\
\hline
\end{tabular}

Sumber: Data diolah peneliti (2016)

Di dalam penjelasan tersebut sudah diberikan formulasi berupa persentase berat bahan baku dan estimasi harga produksi pembuatan sabun cuci cair yang dibuat mulai dari 100-gram, 500-gram, dan 1000 gram.
Pada percobaan ini, dilakukan demonstrasi pembuatan sabun cuci cair dengan jumlah kuantitas sebesar 500gram atau setara dengan $500 \mathrm{ml}$, dimana estimasi harga produksinya sebesar $\mathrm{Rp}$ 2.580 atau setara dengan Rp 2.600 . 
Tahapan proses pembuatan sabun cuci cair ini sangat mudah dan sederhana, satu per satu bahan kimia dicampurkan sesuai urutannya ke dalam wadah gelas kemudian diaduk merata sampai semua bahan tercampur dengan baik dan selanjutnya sabun cair tersebut dituang ke dalam botol untuk siap digunakan.

Tabel 3. Perbandingan Harga Sabun Cuci Cair Sederhana terhadap Sabun Cuci Cair di Pasaran

\begin{tabular}{|c|c|c|c|c|}
\hline No & $\begin{array}{c}\text { Nama } \\
\text { Produk }\end{array}$ & Netto & Harga & $\begin{array}{c}\text { Hemat } \\
\text { Penge } \\
\text { luaran } \\
(\%)\end{array}$ \\
\hline 1 & $\begin{array}{l}\text { Sunlight } \\
\text { Refill }\end{array}$ & $\begin{array}{l}400 \\
\mathrm{ml}\end{array}$ & Rp 7.100 & - \\
\hline 2 & $\begin{array}{l}\text { Mama } \\
\text { Lemon }\end{array}$ & $\begin{array}{l}400 \\
\mathrm{ml}\end{array}$ & $\mathrm{Rp} 7.400$ & - \\
\hline 3 & $\begin{array}{l}\text { Sabun } \\
\text { Cuci Cair } \\
\text { Sederhana }\end{array}$ & $\begin{array}{l}500 \\
\mathrm{ml}\end{array}$ & Rp 2.600 & $\begin{array}{l}55 \\
\%\end{array}$ \\
\hline 4 & $\begin{array}{l}\text { Sunlight } \\
\text { Refill }\end{array}$ & $\begin{array}{l}800 \\
\mathrm{ml}\end{array}$ & Rp 12.300 & - \\
\hline 5 & $\begin{array}{l}\text { Mama } \\
\text { Lemon }\end{array}$ & $\begin{array}{l}800 \\
\mathrm{ml}\end{array}$ & Rp 12.700 & - \\
\hline 6 & $\begin{array}{l}\text { Sabun } \\
\text { Cuci Cair } \\
\text { Sederhana }\end{array}$ & $\begin{array}{c}1000 \\
\mathrm{ml}\end{array}$ & Rp 5.200 & $\begin{array}{l}70 \\
\%\end{array}$ \\
\hline
\end{tabular}

Sumber: Data diolah peneliti (2016)

Berdasarkan hasil perhitungan harga produksi pembuatan sabun cuci cair dengan kapasitas 500-gram (500 ml), bila dibandingkan dengan harga produk sabun cuci cair dipasaran yang paling sering dibeli oleh peserta ibu rumah tangga berupa Sunlight Refill 400 ml (Rp 7.100) dan Mama Lemon $400 \mathrm{ml}$ ( $\mathrm{Rp}$ 7.400), maka dapat diperoleh penghematan pengeluaran konsumsi sabun cuci cair sebesar $55 \%$. Begitu pula dengan kuantitas sebesar 1000-gram atau setara $1000 \mathrm{ml}$ (1 liter) dengan harga produksi sebesar Rp 5.200, maka dapat menghemat pengeluaran konsumsi sabun cuci cair hingga mencapai $70 \%$, jika dibandingkan dengan sabun cuci cair Sunlight Refill 800 ml (Rp 12.300) dan Mama Lemon 800 ml (Rp 12.700).

Dengan adanya penghematan pengeluaran pada konsumsi sabun cuci cair tersebut dapat memberikan pengetahuan kepada ibu rumah tangga untuk mengalokasikan pengeluarannya untuk kebutuhan rumah tangga yang lainnya atau pun membantu mereka untuk melakukan penyimpanan dana (menabung) terkait penghematan pengeluaran ini.

Melalui kegiatan pelatihan ini, akhirnya dapat memberikan keterampilan dan pengetahuan kepada 
ibu rumah tangga kelompok pengajian IKADANA di daerah Srengseng, Jakarta Barat, untuk melakukan produksi sendiri dalam pembuatan sabun cuci cair dalam rangka penghematan pengeluaran konsumsi rumah tangga. Dengan adanya kegiatan ini, para ibu rumah tangga menjadi terbuka wawasannya dan termotivasi untuk menjadikan keterampilan yang mereka peroleh sebagai usaha sampingan atau bisnis rumah tangga (home industry) dalam membantu perekonomian rumah tangga mereka.

\section{KESIMPULAN DAN SARAN}

\section{Kesimpulan}

Berdasarkan uraian diatas, maka dapat disimpulkan hasil kegiatan pengabdian pada masyarakat, yaitu:

1. Dengan adanya pelatihan pembuatan sabun cuci cair ini kepada ibu rumah tangga kelompok pengajian IKADANA di daerah Srengseng, Jakarta Barat, hampir semua peserta sudah memahami proses pembuatannya dan sejauh ini mereka tertarik untuk mencoba lebih lanjut dirumah mereka masing-masing, dimana salah satu manfaat dari pembuatan sabun cuci cair ini adalah melakukan penghematan pengeluaran rumah tangga, khususnya konsumsi sabun cuci cair.

2. Dengan adanya kegiatan ini, para ibu rumah tangga menjadi terbuka wawasannya dan termotivasi untuk menjadikan keterampilan yang mereka peroleh sebagai usaha sampingan atau bisnis rumah tangga (home industry) dalam meningkatkan perekonomian rumah tangga mereka.

\section{Saran}

Berikut ini saran yang dapat diberikan dalam peningkatan kualitas kegiatan pengabdian pada masyarakat, diantaranya:

1. Melakukan evaluasi dan kontrol secara berkala terhadap peserta ibu rumah tangga kelompok pengajian IKADANA di daerah Srengseng, Jakarta Barat, terkait dengan pelatihan pembuatan sabun cuci cair yang sudah mereka lakukan untuk tetap dilanjutkan dan dapat dilakukan dalam rangka penghematan pengeluaran.

2. Kegiatan pengabdian pada masyarakat ini dapat terus dikembangkan dengan melakukan variasi pelatihan keterampilan yang dapat diterapkan bagi ibu rumah 
tangga kelompok pengajian IKADANA di daerah Srengseng, Jakarta Barat, sebagai peluang usaha baru.

\section{DAFTAR PUSTAKA}

Aprijon. 2013. Kewirausahaan dan Pandangan Islam. Menara, Vol. 12, No. 1.

Dumairi. 2004. Perekonomian Indonesia. Yogyakarta: Erlangga

Jongko. 2009. Sabun Kecantikan: Teori dan Praktek Membuat Sabun Beauty di Rumah. Jakarta.

Longenecker, Justin G., Moore, Carlos W., dan Petty, J. William. 2001. Kewirausahaan Manajemen Usaha Kecil. Jakarta: Salemba Empat.

Meredith, Geoffrey G., et al. 2003. Kewirausahaan Teori dan Praktek. PPM.

Shciffman, L. G. dan Kanuk, L. L. 2010. Consumer Behavior, $10^{\text {th }}$ edition. USA: Pearson Education, Inc. 